\title{
Youth lyrics, street language and the politics of age: contextualising the youth question in the Third Chimurenga in Zimbabwe
}

\begin{abstract}
In 2007 Zimbabwean public radio and television banned the airplay of certain urban grooves songs. The lyrics of the songs are analysed in this paper which argues that together, the lyrics and the ban point to intergenerational tensions. Some of these tensions revolve around use of local languages. Whereas the 75 per cent local content policy sought an anti-imperialist popular culture seen in use of local languages and local media products, youths use vernacular languages to highlight intergenerational sex differences in heterosexual behaviour. They use street language which, though not ordinarily accessible to adults, has been an incisive critique of adult sexual excesses. This paper uses textual analysis to show that the banned songs provide an insight into youth subjectivities in social contradictions of Zimbabwe's socio-economic and political crises.
\end{abstract}

\section{Introduction}

Research on Zimbabwe's post-2000 social history, socio-economic and political and development has been dominated by debates of narratives, practices, inherent contradictions and incoherence of the Third Chimurenga. ${ }^{1}$ Embedded in the Third Chimurenga and its academic critiques is the 'youth question' - alarm at the visibility of young people hanging around with nothing meaningful to do. Debates have featured youth as recruits in the national youth service some of whom became members of militias implicated in political violence; ${ }^{2}$ and

\footnotetext{
${ }^{1}$ For instance, J Fontein, -'Anticipating the Tsunami: rumours, planning and the arbitrary state in Zimbabwe', 2009, Africa, 79, (4) pp368-398; J Muzondidya, 'Jambanja: ideological ambiguities in the politics of resource ownership in Zimbabwe' Journal of Southern African Studies, 35, 4, 2009, pp955-965; Bratton, $\mathrm{M}$ and $\mathrm{E}$ Masunungure, 'Popular reaction to state repression: Operation Murambatsvina in Zimbabwe', 2006, African Affairs 106 pp26-45; S J Ndlovu-Gatsheni, and W Willems, 'Making sense of cultural nationalism and the politics of commemoration under the Third Chimurenga in Zimbabwe' 2009, Journal of Southern African Studies, 35 (4); A Y Kamete, 'Planning versus youth: stamping out spatial unruliness in Harare' (2008), Geoforum, 39 pp17211733; M. Rupiya, 'Zimbabwe: Governance through military operations' African Security Studies Review (2005), 14 (3) pp 117-8; F Musoni, 'Operation Murambatsvina and the politics of street vendors in Zimbabwe' 2010 Journal of Southern African Studies 362 pp301-317

${ }^{2} \mathrm{~T}$, Ranger, 'Nationalist historiography, patriotic history and the history of the national: the struggle over the past in Zimbabwe' Journal of Southern African
} 
youth artists who performed in enhanced commemorative events in the creation of 'cultural nationalism'. ${ }^{3}$ In these debates youth are seen as passive pawns in the hands of powerful politicians. This paper argues that far from being pawns, unemployed youth responded to Third Chimurenga policies such as, the 75 percent local content policy, in anticipation of changing their lives, by recording music, a vocation previously frowned down at. Hip-hop, a form of music more amenable to production in low technology environments and its 'glocality', ${ }^{4}$ hence adaptability to different cultures across the world was also became a style of choice for Zimbabwean youths. Music, especially hip-hop, creates a means of self-creation, reflection on shared aspirations and experiences. In some instances, hip-hop has made youth popular politicians for expressing popular sentiments and aspirations; ${ }^{5}$ particularly where institutional arrangements are not open to all. ${ }^{6}$ This paper focuses on lyrics of urban grooves songs banned seven years after this Zimbabwean variant of hip-hop emerged ${ }^{7}$ arguing that the ban

studies, 30 (10), pp215-234; Solidarity Peace Trust, 'National Youth Service training: shaping youths in a truly Zimbabwean manner' (2003), South Africa ${ }^{3}$ Ndlovu-Gatsheni and Willems, 2009, ibid

${ }^{4}$ R. Robertson, 'Glocalisation: Time-space and homogeneity-heterogeneity', 1995, in M Featherstone, S Lash and R Robertson (eds) Global Modernities London: Sage Publications pp25-44

5 J Nyairo and J Ogude 'Popular music, popular politics: unbwogable and the idioms of freedom in Kenyan popular music' (2005) African Affairs 104 pp225249; A Perullo, 'Hooligans and heroes: youth identity and hip-hop in Dar es Salaam, Tanzania' in Africa Today 51 4, (2005), pp75-101; J A Saavedra Casco, ' The language of the young people: Rap, urban culture and protest in Tanzania' in Journal of Asian and African studies 41, 3 (2006) pp229-248; H Becker and N Dastile, ' Global and African: expressing hip-hop artists in Phillipi township, Cape Town' in Anthropology Southern Africa 31, 1and 2 (2008) pp20-29.

G. Steingo, 'South African music after apartheid: kwaito, the "party politic", and the appropriation of Gold as a sign of success' in Popular Music and Society 28 3 (2005) pp 333-357; C Kurbin, 'Gangstas, thugs and hustlas: identity and the code of the street on rap music' (2005) Social Problems 52 (3) pp360-378; A, Clay- " "Keepin' it real": black youth, hip-hop culture, and black identity' in The American Behavioral Scientist 40, 10 , (2003) pp 1346-1358; F B Nyamnjoh and J Fokwang, 'Entertaining repression: music and politics in postcolonial Cameroon' in African Affairs, 104, (2005) pp252-274;

${ }^{6} \mathrm{~F}$ Rossi, 'Youth political participation: is this the end of generational cleavage?' (2009) International Sociology 24 (4) pp467-497

7 S. Nyamhangambiri, 'Urban grooves blacklisted by state radio', (24 October 2007), in www.freemuse.dk (accessed 20 May 2010) 
points not only to differences between youths and officials' concerns but also intergenerational tensions because of adults' excesses.

The youth question in global, regional and Zimbabwean terms

Since the 1980s and 1990s, youth in the global north were labelled as 'slackers', ${ }^{8}$ politically 'apathetic', undisciplined' and 'lazy' ${ }^{9}$ in the US and UK and in Sub-Saharan Africa as a 'lost' ${ }^{10}$ or 'sacrificed ${ }^{11}$ generations to describe the despair of unfulfilled promises of independence. These labels serve a double purpose of directing the spotlight on youth as inadequate or innately delinquent thereby removing attention from policy failures. The labels also divert attention from intractable effects of global economic restructuring which have left many youth unemployed even when they have university qualifications. Although effects of globalisation are different in the global north and south, the fact that in both regions there is a blame-the-victim stance, fear of growing criminality and anti-social behaviour associated with chronic unemployment which sometimes manifests as mistrust of youth, shows deep-seated tensions in the 'politics' ${ }^{12}$ and political economy of age.

In most of Sub-Saharan Africa, there is fear that disenfranchised youth constitute a 'natural opposition' to incumbent governments. ${ }^{13}$ Some such youths are easily recruited into vigilante groups and rebel armies fomenting strife, fragmentation and a crisis of law and order which has

\footnotetext{
${ }^{8} \mathrm{R} J$ Heiman, 'The ironic contradictions in the discourse on Generation X or how 'slackers' are saving the capitalism' (2001) in Childhood 8 (1), pp274-292 
come to characterise the region. ${ }^{14}$ Typical reactions have been to harness the delinquency for individual politicians' and elites' benefits. ${ }^{15}$

In Zimbabwe, as the political tide turned in 2000 on the back of economic stagnation and chronic unemployment, the then ruling party ZANU-PF's panic was targeted at unemployed youth. Party officials paternalistically labelled youth as 'born frees' -because they were born after independence - apparently privileged for it and not able to appreciate what it means to be 'born free'. Officials argued that born frees were susceptible to foreign influence seen in supporting the then nascent opposition party Movement for Democratic Change (MDC); and ideals such as democracy, human rights whose post-Cold war accents are seen as imperialist. ${ }^{16}$ On the basis of age, youths were accused, of lacking experiences of colonialism and therefore being ignorant of workings of imperialism. Further, it was argued that support for the MDC amounted to trivialising the sacrifice of liberation war activists and combatants and that youth took 'Independence' for granted. For many youths however, if Independence promised improved quality of life they were yet to experience it; this was the bone of contention. Since the late 1980s, many school leavers had to contend with receding opportunities for wage employment, inflation of qualifications and growing favouritism which excluded them from available work. ${ }^{17}$ By the 1990s many youths left school faced with long term unemployment,

${ }^{14}$ For instance, see P M Kagwanja, 'Power to Uhuru: youth identity and generational politics in Kenya's 2002 elections' African Affairs 105, pp51-75; S Simonse, 'Warriors, hooligans and mercenaries: failed statehood and the violence of young male pastoralists in the Horn of Africa' (2005) in J Abbink and A van Kessel (eds) Vanguard or Vandals? Youth politics and conflict in Africa pp 243-266; Leiden: Brill; K Peters and P Richards, "Why we fight": voices of youth combatants in Sierra Leone' (1998) Africa 682 pp183-210; K. Meagher, 'Hijacking civil sociality: the inside story of Bakassi vigilante group in South East Nigeria' (2007) Journal of Modern Africa Studies, 45 (1); O. Ismail 'The dialectics of 'junctions' and 'bases': Youth in securico- commerce and the crises of order in downtown Lagos' 2009 Security Dialogue 404 pp 463-487; I.

Abdullah, "I am a rebel": Youth culture and violence in Sierra Leone' (2005) in A Honwana and F de Boeck (eds) Makers and breakers: children and youth in postcolonial Africa London: James Currey

${ }^{15}$ For instance, Meagher, 2007, ibid, also Kagwanja, 2005 ibid

${ }^{16}$ Ndlovu-Gatsheni and Willems, 2009, ibid, p952, Simonse, 2005 ibid

${ }^{17}$ P Bennell and M Ncube, “ “Jobs for the boys?”: employment experiences of secondary school leavers in Zimbabwe' (1994) Journal of Southern African Studies 202 pp301-316, 
poverty, declining quality of urban services because of limited investments and growing overcrowding. ${ }^{18}$ In addition 'born frees' were the first cohorts to be 'child-headed households', abandoned by kin and neglected by neighbours under economic stress after their parents died of AIDS. The state was unable to meet their growing needs because of insufficient coverage of safety nets. ${ }^{19}$ With an estimated one million orphans since the late 1990s when the impact of the AIDS pandemic hit, ${ }^{20}$ circumstances of many born frees spoke of unprecedented hardship and disaffection. These youths were also the first cohorts to be homeless in large numbers in towns surviving on begging. Many youths had flocked to cities in the hope of finding work only to be seen as a social and security threat.

Although the performing arts (singing, dancing and street theatre) became means by which male and female youth sought fame and fortune; these forms of employment were still despised as inferior, morally depraved, ${ }^{21}$ unruly as artists performed anywhere they could attract spectators without paying levies to local authorities; the vocations received little attention in vocational schools and limited policy support to import equipment, to provide appropriate venues and publicise budding talent. That youth survival strategies were misunderstood and got little sympathy is seen in Kamete describing unemployed youth in Zimbabwe as an emerging 'underclass', characterised by 'work averseness' seemingly content living by their wits on the streets through criminality and hustling, thereby undermining personal security in towns. ${ }^{22}$ Not only does the notion of an underclass run counter to reason as it makes it seem as if unemployment and criminality are deliberate choices on the part of youth from low-income backgrounds; it is patronising given the reality of unemployment. In subsequent work, Kamete concedes that youth in the informal sector were targets of Operation Restore Order (ORO) for their 'unruly' informal sector activities. ${ }^{23}$ The reality is even before ORO

\footnotetext{
${ }^{18}$ C. M. Nherera, 'Globalisation, qualifications and livelihoods: the case of Zimbabwe' (2010) Assessment in Education policy: Principles, Policy and Practice 73 pp335-363 
the government took to rounding up homeless youths and deporting them to resettlement farms to prevent 'vagrancy', unruliness, hustling and in response to calls for better security. Thus the question of youth unemployment and poverty is at the core of the Zimbabwe crisis albeit a policy blind spot hence could not be dealt with coherently.

Driven by the view that youths are spoilt brats or bent on undermining the government, officials hastily put together policies which sought to 're-educate', discipline, indoctrinate and control youth to appreciate selective strands of Zimbabwean nationalist history. This was done through the National Youth Services, with unsustainable carrot and stick mechanisms where trainees were promised preferential treatment in vocational colleges. ${ }^{24}$ There was talk of encouraging self-employment through micro-credit schemes run by the ministry, the impact of which is open to speculation given the paucity of skills in youth and development programming. To capture hearts and minds of more urban residents and youths, budding youth artists were allowed to perform at state functions -the enhanced commemorative events of cultural nationalism. Whereas previously, recording companies had a static view of Zimbabweans' music preferences and routinely rejected new styles of music, especially hip-hop, on grounds that they would 'not sell', ${ }^{25}$ now youths could publicly perform their pieces with live television coverage; but still no infrastructure for selling products. In addition, the '75 percent local content' for public radio and television increased possibilities for budding artists as broadcasters scrambled for local products. ${ }^{26}$ Urban grooves emerged under this context, before the decade ended some artists' songs ran afoul with the officials on grounds of unsavoury lyrics.

\footnotetext{
${ }^{24}$ Because of structural challenges such as economic stagnation, the capacity of colleges to absorb students was already stretched to the limit. In any case, the promise was not to waive the usual entry requirements, thus national youth service was an extra requirement for those most desperate to get training and jobs.

${ }^{25}$ B. Eyre, Playing with fire-fear and self-censorship in Zimbabwean music, (2005) Freemuse: Copenhagen; T. Kupe, 'The meanings of music: the presentation of popular music in Zimbabwe, in African Identities, (2003), 12 pp187-196; M. Chikowero, " "Our people father, they haven't learned yet": Music and postcolonial identities in Zimbabwe, 1980-2000' in Journal of Southern African Studies (2008), 341 pp145-160

${ }^{26}$ See Eyre, 2005, ibid
} 


\section{Methods}

The paper uses textual analysis on lyrics of select songs to show emerging intergenerational and gender identities and struggles. I accessed the banned songs (see Table i) and a few others with similar themes from YouTube whence I transcribed, and translated portions of songs I cite. Textual analysis as elaborated by Fursich, McKee and others is guided by the belief that cultural products and forms of art including lyrics are patterned 'texts' which in various ways reflect and reveal ideas about cultural norms and values, identity, economic and political and social struggles in their context. ${ }^{27}$ As a corollary and component of these struggles, people relate to 'texts' differently depending on their socioeconomic status, gender, race and ethnicity. ${ }^{28}$ Meanings of texts are contestable especially because music lyrics are not produced and consumed in a social vacuum. With regards to hip-hop controversy abounds because of its association with criminality, misogyny, homophobia and other forms of hate speech. ${ }^{29}$ In the African context, its performance by youth commenting on social goings-on has led to disapproval by adults. ${ }^{30}$ By analysing songs that ran afoul with officials, it is possible to see interrelationships and tensions between youth concerns and political elites' preoccupations, what is at the centre and periphery of what is struggled over in the protracted political crisis in Zimbabwe.

\section{Urban grooves as part of a global youth culture}

Urban grooves is a hybrid of US hip-hop, $R$ and $B$, and rap, as well as Caribbean/US/UK ragga (dancehall music) and South African kwaito. It is dominated by male artists. ${ }^{31}$ Drawing on hip-hop's penchant for 'keepin' it real' as described by Andreana Clay ${ }^{32}$, that is, publicising subjectivities of marginal groups, whose views are not listened to, urban grooves

\footnotetext{
${ }^{27}$ E Fursich, 'In defense of textual analysis: restoring a challenged method for journalism and media studies' in Journalism Studies 102 (2009) pp238-252

${ }^{28}$ For instance, A. McKee, Textual analysis: a beginner's guide, (2003) Sage Publications, London and R, Woffitt, Conversation analysis and discourse analysis: a comparative introduction, (2005) Sage Publications, London

${ }^{29}$ For instance, C. Kurbin, 'Gangstas, thugs, and hustlas: Identity and the code of the street in rap music' Social Problems 523 (2005) pp360-378

${ }^{30}$ For instance, Perullo, 2005, ibid

${ }^{31}$ These artists should not be confused with artists commissioned to perform chave chimurenga jingles on public radio as none dealt with in this paper performed materials used for that campaign.

32 Clay, 2003, ibid; Perullo, 2005, ibid
} 
does the same for Zimbabwe. Urban grooves uses humour, satire and stereotypical voices of the marginalised. Its novelty was twofold: reference to everyday events in urban spaces and lyrics in Shona and Ndebele albeit colloquial. The latter seemed in compliance with calls for 'local' (as opposed to foreign produced and English language imports) media products while the former could be because of repression and fear of reprisals typical in the post-2000 political climate.

Urban grooves has been described as 'non-confrontational', ${ }^{33}$ but in fact part of emerging popular politics characterised by ad-hoc activism because of exclusion from established institutional arrangements such as political parties and trade unions. ${ }^{34}$ Performing artists and their products are easily ignored by the public and politicians until their lyrics resonate with popular sentiments at which point artists risk being banned or co-opted into agendas of the powerful. ${ }^{35}$ When youth publicise issues that elites would rather are not talked about, claims of 'impropriety of lyrics' are used to police and silence them; ${ }^{36}$ a handy tool for managing generational politics in Sub-Saharan Africa. ${ }^{37}$

Globally hip-hop and its variants are controversial in their spaces of origin. At first, they seemed aligned to liberatory quests of marginalised and minority groups. ${ }^{38}$ Latterly they are seen as (mis)representing black cultures as hedonistic (hence predominantly party music), given to criminality, ostentatious consumerism, hypersexuality, misogynistic and play into age old racial stereotypes thus extending inferiorisation by shying away from political/message driven lyrics of their predecessors. ${ }^{39}$ Consequently, these music genres are seen as subversive, undermining their own communities. Still, hip-hop has a counter-narrative of black (women's) bodies as beautiful and desirable. In this vein these music types expose evolving 'economies of desire' which paradoxically challenge and reaffirm existing stereotypes of class, race, and gender through repackaging some groups and their stereotypes for the

\footnotetext{
33 I. Manase, 'Zimbabwean urban grooves and their subversive performance practices' in Social Dynamics 351 (March 2009) pp56-67

${ }^{34}$ Nyamnjoh and Fokwang, 2005, ibid; Nyairo and Ogude, 2005, ibid; Rossi 2009, ibid p468

${ }^{35}$ For instance, Nyairo and Ogude, 2005, ibid p232-244 Nyamnjoh and Fokwang, 2005, ibid; p253, 266

${ }^{36}$ M. Miller-Young, 'Hip-hop honeys and Da Hustlaz black sexualities in the new hip-hop pornography' in Meridians: feminism, race, transactionalism 8, 1 (2007) pp261-292

${ }^{37}$ Perullo, (2005) ibid; J A Saavedra Casco, 2006 ibid; H Becker and N Dastile, (2008) ibid

${ }^{38}$ Kurbin, 2003, ibid; Miller-Young 2007, ibid

${ }^{39}$ M. Miller-Young, 2007 ibid; Kurbin 2005 ibid; Clay 2003 ibid; Perullo 2005 ibid.
} 
entertainment industry. ${ }^{40}$ As consumption of this music widens, some artists in rich countries have become wealthy. For many marginalised youth, these music styles have become means to fame and fortune in contexts where other avenues for upward social mobility are not available. Thus these genres cannot be dismissed as singularly objectifying women (and black people) without grappling with their contradictory narratives and effects. In Zimbabwe, too some of youth artists sing about evolving consumerism, changing economy of sexual desire and moral economy in an economic crisis and high HIV prevalence.

The stature of urban grooves is debatable ${ }^{41}$ with some arguing that it is 'controlled' by the state, ${ }^{42}$ while some government officials recently said urban grooves spurs youth enterprise; ${ }^{43}$ and therefore a laudable response to unemployment albeit lacking technical expertise and material resources. Urban grooves has yet to spawn a youth culture in the form of youth radio stations, lifestyle magazines, fashion, nightclubs and websites; or to produce affluent artists (celebrities) out of previously impoverished youth, like in other Sub-Saharan countries. ${ }^{44}$ The music industry in general in Zimbabwe, and especially budding artists have to contend with negligible investments, low returns and amateurism not withstanding government's expedient support through the 75 percent local content policy. Piracy by unemployed youths and poor organisation of distribution and marketing of products continue to dog the industry. ${ }^{45}$ Being an artist continues to carry an air of despair; youth artists themselves tease each other about it as shown below.

Most artists use stage names such as Maskiri, (Alishias Musimbe), Xtra Large (Norman Manuwere and Jimmy Mangezi), Shayndingz (Shayne Ndingindwayo), Nasty Trix (Trust Dojiwe), Decibel (Daniel Mazhindu) and Sniper (Donald Chirisa) to mention a few whose productions are discussed below. These artists are among some of the first and the most well known. ${ }^{46}$ Xtra Large are an award winning pair, while Maskiri's

40 Kurbin 2005 ibid, Clay 2003 ibid; and Miller-Young 2007 ibid among others

${ }^{41} \mathrm{~F}$. Tichawangana, 'Urban grooves is dying' in www.zimbojam.com (25 May 2009) accessed 2 August 2010. Debates are on-going on ZBC television youth music programs Heart of the Rhythm and Urban Limelight

${ }^{42} \mathrm{~W}$. Bere, 'Urban grooves: the performance of politics in Zimbabwe's hip hop music' (PhD Thesis, New York University (USA), 2008); also Manase, 2009 ibid.

${ }^{43}$ Minister of Youth, Indigenization and Empowerment, Mr Saviour Kasukuwere, interviewed on ZBC TV, on 18 December 2010.

${ }^{44}$ G. Steingo, (2005) ibid; also Perullo 2005 ibid.

${ }^{45}$ For instance, Kupe 2003, ibid; Chikowero 2008, ibid

${ }^{46}$ There are complaints about exclusion of emerging artists. http://xbcjumpoff.blogspot.com (accessed 18 May 2010) 
notoriety for sexually explicit lyrics precedes him. Sniper is an upcoming dancehall artist.

Table i: Description of songs analysed in this paper

\begin{tabular}{|c|c|c|}
\hline Name of artist & Song & What the song is about \\
\hline Decibel & Madhara & Intergenerational /transactional sex \\
\hline Maskiri & Zimhamha & Intergenerational sex \\
\hline Maskiri & $\begin{array}{l}\text { Madam } \\
\text { Mombeshora }\end{array}$ & Intergenerational sex \\
\hline Xtra Large & $\begin{array}{l}\text { Small house } \\
\text { (from an album } \\
\text { of the same } \\
\text { name) }\end{array}$ & Extramarital affairs \\
\hline $\begin{array}{l}\text { Xtra Large with } \\
\text { Sniper }\end{array}$ & $\begin{array}{l}\text { *Aiwa mukoma } \\
\text { (from the album } \\
\text { 'Still at Large') }\end{array}$ & Extramarital affairs. \\
\hline Xtra Large & $\begin{array}{l}\text { House gero } \\
\text { (from 'Still at } \\
\text { large') }\end{array}$ & Extramarital affairs \\
\hline Nasty Tricks & Chi-danger & Peer- to-peer desire \\
\hline $\begin{array}{l}\text { Shayndingz, } \\
\text { with Maskiri } \\
\text { and Diana }\end{array}$ & $\begin{array}{l}\text { *Celebrity } \\
\text { (a single) }\end{array}$ & Peer-to-peer desire \\
\hline $\begin{array}{l}\text { Jerry, with } \\
\text { Shayndingz, } \\
\text { Maskiri and } \\
\text { others }\end{array}$ & $\begin{array}{l}\text { *Tipei maoko } \\
\text { (from the } \\
\text { compilation } \\
\text { album 'Chigutiro } \\
\text { Phase 2, 2006') }\end{array}$ & $\begin{array}{l}\text { Hedonism, adultery, partying and } \\
\text { bingeing on alcohol }\end{array}$ \\
\hline Dino Mudondo & $\begin{array}{l}\text { Jatropha (from } \\
\text { the album } \\
\text { 'Rasta Kwasa'- } \\
2007 \text { ) }\end{array}$ & Marital life- a woman's perspective \\
\hline
\end{tabular}

* Not on the list of banned songs but added here for illustration.

a) Emerging subjectivities: street language, new noun prefixes and the destabilisation of the honorific plural

Street Shona does not obey linguistic rules as it reworks grammar through a creative use of noun prefixes and proverbs to create new meanings. This is disconcerting to purists which to my mind includes 
many adults, cultural gurus and government officials. Urban grooves' use of street Shona challenges attempts at presenting dignified subjectivities as part of cultural nationalism. In contrast, Standard Shona is a Southern Bantu language, examined from primary school to university level. It is insulated from different versions of everyday Shona with translation of technical terms in other languages a perennial challenge. Like all languages, standard Shona has language rules, which in its case includes 21 classes of nouns differentiated by whether they refer to objects, persons, places and so on. For example 'munhu'/'person' (genderless) is a class 1 noun followed by its plural version 'vanhu' meaning 'people' and the honorific plural used for kin relations such as mother, father, grandmother/mother-in-law/aunt, uncle/grandfather and so on such as 'amai'/ 'mhamha', 'baba', ambuya, asekuru respectively class 2 . If a person is qualified as an idiot, mentally ill, a thief, prostitute or person with disability, class 1 noun classification is no longer applicable. Instead other classifications apply; all widely seen as dehumanising and outside the socially and morally accepted. ${ }^{47}$ The prefixes this involves are used by Street Shona in ways understood to demean men and women, removing them from inherent class 1 and 2 respectability. Often this use is linked to consumerist criteria (access to disposable income and extent to which it is shared with others) and sexuality are used moving this language away from cultural notions of non-disclosure of sexual practices and humility vis-à-vis personal wealth. This makes street Shona crude sound and disrespectful.

The charge of disrespect and inappropriate language is seen in the song 'Zimhamha' by Maskiri. Referring to a 'sugar mama', Maskiri uses the noun prefix zi- with the word mhamha (informal reference to 'mother', a classificatory reference to older women); this $z i$ - prefix gives the image of someone grotesque in behaviour, body shape, extreme/excessive, deviant or out of place and/or unusual. Thus, the zi-prefix shows the older woman in less favourable light, no longer accorded class 1 respectability as amai. As Lafon says, the prefix zi- is 'very awkward', could be 'derogatory' and is 'preferred by youth' to describe people and objects alike. ${ }^{48}$ It belittles and caricatures the subject. In gerontocratic settings in Zimbabwe the zi- prefix is inappropriate when referring to adults. ${ }^{49}$ It allows Maskiri's alter ego to strip the older woman of

\footnotetext{
${ }^{47}$ For instance, the term chirema (English equivalent is 'cripple'), seen as demeaning by activists who prefer the descriptive phrase 'mwana/munhu akaremara' (that is, 'person/child with disability'). The former persists in everyday language.

${ }^{48}$ M. Lafon, 'Shona class 5 revisited: a case against * $R i$ - as class 5 nominal prefix' in Zambezia 201 (1994), pp 51-80, p69, p73

${ }^{49}$ Another example is the street term mazirudo calibrated from 'rudo' meaning 'love'. Mazirudo means 'lots of awkwardly big love' because of use of two prefixes zi- (as discussed above) and ma- (indicating quantity). Such love is
} 
respect and to engage in conversation on intimate subjects of sex, love and desire thereby shrinking social distance with her. The zi- prefix thus destabilises inherent respect of 'mothers'.

The song starts with a chorus, repeated several times in which Maskiri chants alternate lines with a female colleague singing the sugar mama's lines as if in conversation. It goes,

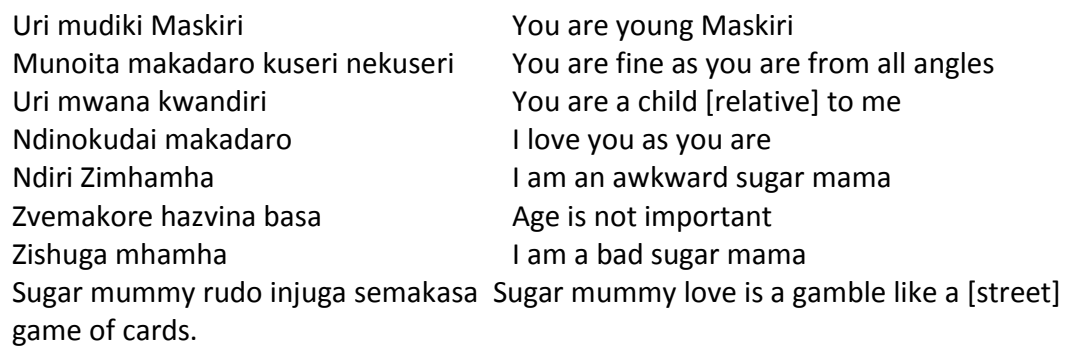

Even when told that he is 'a child...' Maskiri's alter ego refuses to take the place of a child/junior person who obeys elders. He talks back and rebuts the older woman's arguments. Later in the song, Maskiri uses thinly veiled figurative speech in favour of his virility, ability to provide economically, to please socially and sexually. On virility he says there is 'so much of him' if he were a water body he would be 'an ocean', compared to milk he would be 'as thick as sour milk' and able enough to 'drive a bus'. His lyrics show age and gender relations in chaos. Whereas the blueprint of patrilineal patriarchy is such that women gain respect as they get older, here we are presented with a situation where women are subjugated conjugally by young men with resources. The lyrics also show that age per se is no longer important rather the ability to command resources, accumulate disposable income and perform sexually are means to respect. To the extent that such sexual relationships between older women and younger men happen, they remain a source of embarrassment in Zimbabwe. They are part of gossip. These relations are not publicised especially by young protagonists seemingly happy with their exploits as it shames women who lose neo-patrilineal respect as 'mothers'. ${ }^{50}$ In these lyrics, such relations show women as deviant because they are having sex with 'their children'.

Shrinking distance between different genders and age groups is further illustrated by the same artist in the song Madam Mombeshora, about a male student fantasizing about marrying his female teacher. Female teachers are doubly respected, first as female elders and as symbols of

hard to imagine, insincere and therefore repulsive. It denotes an uncharted territory underlined by uncertainty of intentions, cynicism and insincerity. ${ }^{50}$ Vanamai in Shona. 
authority and a means to academic knowledge and professional qualifications. Female teachers should be out of bounds as objects of sexual desire. The fantasy begins when a new lady teacher, Madam Mombeshora sits 'improperly' ('...vasina kugara zvakanaka') in front of the class. This conjures up images of exposed underwear or thighs. In professions such as teaching with clear dress codes, women, to mark the respect they are due, are expected to cover their bodies from below the knee upwards. In the event of deliberate or accidental exposure, male juniors are expected to avert their gaze. In this case, a male student goes to the teacher to warn her himself. Rather than correcting herself, the lady teacher seems to enjoy the attention and extends the impropriety by flirting with the student. She does not use her position as a figure of authority to reprimand the student. The teacher dies in a car accident the following morning and the song ends as a lament about what could have been. Outside school settings, the shrinking of distance between people in the workplace, for example, widely employs fictive kinship to modify chains of command and impersonal workplace procedures thereby changing organisational procedures. Thus this lyric comments on a more widespread process whose effects are not fully acknowledged in public discourse.

Another example of creative use of noun prefixes is use of plural prefixes for persons not in class 1, for example ma- such as in madhara. In Street Shona ma- emphasises qualities of the subject. Hence the 'big dhara' is interchangeable with madhara; suggesting that ma- serves the same purposes as 'big'. The term madhara is not known to standard Shona having been borrowed from the Ndebele word 'umdala' where, as an adjective it means being old/mature and is genderless. As a noun it means an old/mature man. In street Shona madhara refers to men, regardless of age, who excel in ostentatious consumption by mastering/excelling in the unregulated and grey livelihood strategies of the kukiya-kiya economy ${ }^{51}$ by bingeing on alcohol (and sharing with other men, of course), and/or attracting beautiful women, and are admired by the speaker(s). This is in evidence in Jerry, Shayndingz, Maskiri and others' song Tipei maoko, a chest thumping song, in which they are 'madhara' through their ability to host all night parties/shows. Used as madhara ematumbu, it signifies age and social status, meaning middle aged men with pot bellies. Newspaper cartoonists caricature pot-bellied men - an oblique reference to politicians or businessmen, showing them with cigars between lips, sunglasses and a Mercedes Benz nearby. Madhara ematumbu are not liked by youth artists as shown in Maskiri's Zimhamha and Decibel's Madhara. These men are portrayed as given to excess, (sexual) exploitation and hypocrisy; cheating on their wives and children. They are scorned for what is seen

\footnotetext{
${ }^{51} \mathrm{~J}$ Jones, " Nothing is straight in Zimbabwe": the rise of the kukiya-kiya economy' in Journal of Southern African Studies (2010) 36, 2 pp285-299
} 
as unfairly gotten wealth but also envied for what the wealth enables the men to do. They are attractive patrons.

In these lyrics, men of limited means are not necessarily sympathised with or spared. They are seen as people of no consequence and/or as nuisances, referred to as 'kamudhara'. Here there is some acknowledgement of maturity but with a twist, because of the prefix kawhich denotes being 'small' or 'socially insignificant'. This prefix is sometimes applicable for children to express helplessness or cuteness. It is patronising. For adults it is belittling and renders them pitiable. References to kamudhara are made in Celebrity by Shayndingz and colleagues. By changing rules of the Shona language, youths create new terms which seem crude and anti-establishment but also show new subjectivities in challenging times where personhood is defined in terms of access to cash, displays of material wealth and ostentatious consumption. Those not able to perform or show off, are belittled while those who excel through exploitation and hypocrisy are told off.

In addition, urban groovers rework proverbs thereby extending original meanings. They show that language is not incontrovertible. For example, Maskiri says in Zimhamha, 'Chembere mukadzi hazvienzani nehanzvadzi' (an older woman could be a partner unlike a sister/cousin). This is based on an original proverb which says, chembere mukadzi hazvienzani nekurara mugota (that is, 'marrying an older woman is better than remaining a bachelor'). Historically this proverb implored young men to conform with hetero-normative imperatives to marry a woman hence any woman was better than no woman at all to affirm (hetero)masculinities. The proverb was recounted to young men who took long to marry or were hesitant to inherit a deceased relative's wife. In Maskiri's version, the desirability of older women is not about implied homophobia of bachelorhood but the need to comply with the incest taboo. This may suggest an awareness of youth having incestuous sex while claiming to be abstinent. As young men stay single well into their thirties because of unemployment and inability to amass resources to marry, older women may be a safe source of sex for young men inclined to have sex when female peers bound to abstinence teachings are inaccessible. Urban groovers not only bring into public debate less talked about sexual practices, they also create own renditions of proverbs tinged with irony, cynicism and glimpses of changing personhoods in urban areas. Their unconventional use of noun prefixes re-categorises older men and women to render respect conditional on behaviour rather than mandatory. This must be hard to relate to for people of older generations, who would rather these subjectivities are dismissed as flights of fancy and deviant. Thus street Shona is seen as corruption of standard Shona, and an embarrassing sideshow in the cultural nationalist project.

\section{b) Obscenity as sexually explicit lyrics}


The second basis for banning urban grooves is on the grounds of its sexually explicit language, especially that this is stated publicly (as is inevitable with music). As Eyre notes, '... an aversion to public expression or discussion of sex goes back at least to the colonial period...few in [Zimbabwe] complain about it' ${ }^{52}$ Over the years, this has caused sexually explicit traditional poetry to be sidelined in school curriculum because it is embarrassing. For instance, lovers' poems called Zvirevereve zvemugudza (more precisely, 'recitals whispered in the blankets') performed in the privacy of heterosexual relations. On such poem, referred to by Shire has its protagonist, a woman praising her partner's virility, describing sexual desire, sensations of sexual stimulation and pleasure using figurative speech. ${ }^{53}$ In the past, these poems were learnt in patrilineal kin settings with maternal uncles and paternal aunts teaching nieces and nephews. This knowledge, with urban migration, families nuclearizing and traditional registers marginalised, is being lost. The poems describe events, body parts, and sensations in language teachers find embarrassing. ${ }^{54}$ The sidelining of this traditional sexually explicit literature helps to create an image of a culture in which sexual naïveté, implied by ignorance, is a virtue. ${ }^{55}$ There is no agreement as to where and when sexually explicit materials are appropriate given changing communication technologies, living arrangements and demands of public health such as HIV and AIDS. The latter, in particular, challenges notions of sexual naiveté as a virtue and the need for awareness has permitted contrived discussions of sexuality led by NGOs and state agencies. In popular media products in vernacular languages, through which notions of 'our [sic] culture' are best performed, debated and imagined, sexually explicit materials are sifted out.

Youth artists defy these rules of etiquette of space and time by using lyrics that refer to kissing, passion and desire to audiences of all ages and genders, for instance, songs such as Xtra Large's Small house, Maskiri's Zimhamha, Decibel's Madhara and Shayndingz et al's Tipei maoko. In Small house Xtra Large takes on the persona of an older man of Malawian origin, typically stereotyped as ignorant and speaking Shona with a discernible foreign accent. ${ }^{56}$ Such men are portrayed as

\footnotetext{
${ }^{52}$ Eyre, 2005, Ibid pg 7

${ }^{53} \mathrm{C}$. Shire, 'Men don't go to the moon: language, space and masculinities in Zimbabwe' (1994) in A Cornwall and N Lindisfarne (eds.) Dislocating masculinity: comparative ethnographies London: Routledge pp 145-153

${ }^{54}$ My personal recollections of doing A level Shona. The poems' language was impenetrable and there were no reference materials to aid comprehension.

${ }^{55}$ E. Schmidt, Peasants, traders, and wives: Shona women in the history of Zimbabwe, 1870-1939, (1992) Harare/London: Baobab Books/James Currey

${ }^{56}$ This version of Shona uses the sound ' $L$ ' instead of ' $R$ '. Standard Shona has no ' $\mathrm{L}$ '.
} 
given to enchantment with modernity on the margins because they worked in domestic service for white people in the colonial era, thus had a front seat view of white culture. They regaled locals with their experiences, in a language they had not yet mastered well. For instance, in the song the narrator refers to sitting on a 'double quarter bed' when in reality beds in Zimbabwe are (and were) sold as single, three quarter, double beds and so on. Xtra Large's presentation is humorous albeit ethnocentric. The latter is not referred to in the ban. ${ }^{57}$ The song is based on a post-independence popular song Rudo Imoto by Marshall Munhumumwe about married women who see marriage as an end in itself rather than work in progress. This earlier version suggested that married women apparently stop grooming themselves, become sloppy in housekeeping, thereby pushing their husbands to look for mistresses. Munhumumwe's version is not controversial whereas the urban grooves version is. The latter starts with a chorus in which the artist laments an impending separation with his wife as he contemplates moving in with Amai Linda, his mistress, hence 'small house'. He says

[....]

Ndaenda kumba kwesmall house, sahwila

Ndasika, ndagaliswa padouble quarter bed

[.......]

Andibikila mazai, bhekoni, mabhuluvhosi

[.....]

Mai Linda andiisa lulimi munzeve

Andikisa pahulo sahwila

[......]

Amai Bhoyi kumba havaite zese izozo
I visited my small house Once I got there, she made me sit on a double quarter bed

She served eggs, beacon and boerewors [sausages]

Mai Linda put her tongue in my ear

She kissed me on the neck my friend

Mai Bhoyi [wife] does not do all this

$[\ldots \ldots .$.

Not only is this man taken by the hospitality and romance of his mistress, he will soon leave his wife. To his daughter his daughter who is about to get married, the narrator advises that men prefer attention, good cooking, housekeeping skills and personal grooming on the part of women. If his daughter cannot cope, her husband will leave her as he

\footnotetext{
${ }^{57}$ Muzondidya, 2009, Ibid, p335, on the long established trope of caricaturing of black people of foreign origin as idiots, without rural homes and totems considered important aspects of neo-patrilineal identity. Xtra Large also use other Shona dialects for humour and satire in some of their pieces.
} 
left his wife. In the last verse, a friend of the narrator concurs saying his wife, who recently gave birth is not coping with housekeeping, baby and self-care leading to body odour and an unpleasant smell in the house (due to unwashed nappies). He finds relief at his mistress's.

In Madhara, Decibel impolitely refers to unprotected sex as 'kupisa nyoro'. He shoots from the hip by addressing 'madhara asigade kukura' that is, 'old men who do not act grown up'. This could be read as a call for adults to keep their end of the bargain in norms of observing social distance between people of different ages and genders as part of restoring individual and group decency and dignity. ${ }^{58}$ Only if adults behave well, are they in position to reprimand youth. Decibel says

[...] Ah baba ndaona

Hamunyare

$[\ldots . . .$.

Kukwezva vana nekushandisa mari

$[\ldots . .$.

Kunyepedzera kuvashamwari

Zviri zvemari hanzi 'baby don't worry'

Anything you want I can get you money in a hurry

Chinangwa chako ndechekuputsa have

Mwana wacho, oh, achiri kuchikoro

Dai wambomupawo zororo

Tarira zvino wava kumumwisa doro

Chinangwa ndechekupisa nyoro

Kana vabereki haachamboterere

Arikupika joy mutswerendende

Gare-gare tichagonzwa yavamhere
[...]Ah father I notice You have no shame

[....]

You bait children with money

You pretend to be a friend You say if it's about money, baby don't worry [as written]

Your goal is to satisfy your sexual desire

Oh, the girl is still at school

Please, give her a break

You make her drink

alcohol

Your objective is unprotected sex

She no longer obeys her parents

She is now hooked to having fun In due course there will be heartache

[....]

Older men are portrayed as cunning and manipulative as they 'bait' young girls with money, in order to have unprotected sex, and break their virginity, infect them with HIV then abscond. Madhara undermine a poor parent's authority with their superior resources. Hence madhara are complicit in creating wayward youth. Such men are directly told off by Decibel who says 'Hamunyare' (You have no shame), a strong

\footnotetext{
${ }^{58} \mathrm{~S}$. Heald, 'The power of sex: some reflections on the Caldwells' "African sexuality" thesis' (1998) Africa 654 pp 489-505.
} 
reprimand coming from one younger than the target of this statement, its being public and targeting non-kin. In Shona culture, a person with no shame is as good as a sociopath because shamelessness is linked to deviance, and living outside parameters of propriety, hence being out of control. Given the intersubjectivities of identity and respect, such individuals make it difficult for others to respect them. This is why extramarital and intergenerational sexual relations are conducted in secrecy. This veil of secrecy is lifted by Decibel's lecture; exposing and shaming older men involved and talking directly about their intentions using the street term, 'kupisa nyoro'. Literally, it means 'burning something wet' in this case referring to an aroused penis encountering a lubricated vagina without any protection. In the song, Decibel warns about risks of such an encounter vis-à-vis HIV infection especially for vulnerable girls. However, exposing older men's sexual misdemeanours is widely seen as inappropriate as seen in the furore over threats to name and shame men caught kerb crawling in search of paid sex in Harare in $2004 .{ }^{59}$ At that time men complained that the campaign would destroy their marriages and reputations. The campaign subsequently fizzled with a few arrests and fines and no names. This indicates that telling off male elites is anti-establishment.

Decibel's rap/chant addresses young women and girls too, asking them to have some restraint and challenging their hedonism. He also addresses young men 'baited' by the beauty of young women who date older men and warning them of the hidden dangers of transactional sex. This may be said to stigmatise young women given to consumerism, but Decibel does so no more than academics do in references to the 'feminisation' of HIV and AIDS in Sub-Saharan Africa.

The complaint against Dino Mudondo's Jatropha whose chorus is about a married woman demanding 'her conjugal rights' from an errant husband, ${ }^{60}$ is that it portrays married women and marriage as primarily about sex (as reported in Freemuse). Sex and sexuality are key ingredients of marriage, especially given contexts in which pre-and extramarital sex are seen as illicit and immoral. In neo-patrilineal settings such as in Zimbabwe, marital sex serves group interests of (lineage) reproduction with individual interests such as sexual pleasure subsumed in them. Sexual pleasure as an end in itself is not socially palatable. In human rights discourses sexual fulfilment is presented as right, although in public health discourses, youth are told to wait till marriage to have sex. The need for sexually fulfilling married life for men and women, is increasingly preached by many churches, which also

\footnotetext{
${ }^{59}$ W. Johwa, 'Time's up for "kerb crawlers" ', in Mail and Guardian. August 19 2004. (www.http://mg.co.za/article/2004-08-19-times-up-for-kerb- crawlers (accessed 18 April 2011)

60 She says repeatedly, '...ndipe zvandakakavinga' ('...give me what I came for').
} 
preach the sanctity of marriage. Sex within marriage, say Pentecostal churches can be demanded by married women. ${ }^{61}$ Perhaps questions of women's sexual agency disturb public sensibilities, in particular whether or not the issue can be debated publicly in the process of (re)defining 'African culture'. Otherwise women's sexual agency implies men of questionable virility unable to meet wives' sexual needs, and this is an affront to local masculinities.

As the foregoing tries to show, although older musicians have tackled the same subjects, it is the urban groovers who attract controversy. Their messages about sexuality and comment on local practices are seen as inappropriate as they disclose and expose. However debates on these issues abound in the media, including local talkshows and are preached about in churches without complaint from women's groups or the government. The same message is given in healthcare centres about postpartum self-care. In all likelihood, the same issues are discussed in male spaces too. The difference seems to be that (especially male) youths are talking about them publicly as if to shame older women.

\section{c) Intergenerational tensions: competition for partners between older men and male youths}

There is the question of propriety in gerontocratic contexts where adults talk down at and are obeyed by juniors. In addition, these are contexts where youths should not display their sexual expertise much less comment on adults' excesses in public or challenge them as less ideal partners. Where youths are privy to adults impropriety they should turn a blind eye, not talk about it to avoid embarrassing those involved. Urban groovers challenge these gerontocratic norms by presenting themselves as better partners for unattached older women and as innovative and experienced in new forms of leisure. They are impatient with traditional marriage rites. Examples include, Maskiri in Zimhamha, Decibel's Madhara, Jerry with Shayndingz and others in Tipei Maoko, and Xtra Large with Sniper in Aiwa mukoma.

Maskiri's alter ego tells the sugar mama that he is better than madhara ematumbu whose sense of fun is ridiculed as predictable, described as, rhumba music [music from DRC], having a bar-be-cue and drinking alcohol while their wives and children are waiting for them at home. By contrast, he is available and can take the woman to spaces of recreation off the beaten trail. Decibel deals with older men by simply telling them off he says they should grow up and stop competing with younger men for school girls. Shayndingz et al complain about men of means showering girls with money thus diverting their attention away from

\footnotetext{
${ }^{61}$ R. Mate, 'Women as God's laboratories: Pentecostal discourses of femininity in Zimbabwe' (2002) Africa 72 (4) pp549-568
} 
less well endowed males, as they are. They talk back saying they do not care about such antics, ${ }^{62}$ because they too are determined to have fun and use responses to their chants as a sign that patrons are having fun. They verbally abuse these men using thinly veiled swear words by mentioning parts of the alimentary canal in English and stop with the rectum without mentioning the anus which is typically a crude swear word in Shona. Their use of English hides the swear words somewhat making the lyrics sound like child's play until one notices where they are headed. Their point is made; they basically insult whoever they are talking to.

While the above examples show male youth challenging adults and getting away with it, in Aiwa mukoma adults violently regain their dominance. In the video Sniper acts as an irate married man whose wife has an affair with a young man. Xtra Large do the background singing. As the quoted chorus below shows, the young man attempts to reinsert himself into kin based frames of reference where he is junior (mukomana) relative to the irate man calling him 'big brother', (hence 'mukoma') to plead for mercy.

Aiwa mukoma,
Handizivane na Fiona
Ndiri mukomana anosona
Sandizvo zvamaona
Ndatumwa na Mai Mona
Handinyatsogona Shona
No, big brother, I do not know Fiona I am a boy who mends/sews [tailor/shoe cobbler] This is not what you think I am running an errand for Mai Mona I cannot speak Shona fluently

The married man retorts that such young men think of themselves as 'manly'/'virile' ('vanozviita varume') and so smart that can outfox older men, ${ }^{63}$ this after increasingly ridiculous explanations for being at the man's house. The older man asks his adversary who buys the food he ate? In the video, the older man carries a large bat-like instrument threatening the wayward young man who is shown cowering. The young man is customarily clapping his hands (kuombera) ${ }^{64}$ in a show of humility, respect and appeal for mercy. He says he is a simple and apparently obedient neighbourhood shoe cobbler/tailor, running errands between two women, Mai Mona and Fiona (wife of angry man). He pre-empts further questions saying his Shona is not fluent and that the angry man is jumping to conclusions. The young man's pleading adds insult to injury because of reference to his lover by first name, a sign of familiarity and deletion of the woman's status as wife and

\footnotetext{
${ }^{62}$ Saying 'Hatina basa nemi'

${ }^{63}$ Saying '....kuzviketa tsotsi' (that is, 'making oneself a scamster', 'living by their wits' or 'getting things by illicit means').

${ }^{64}$ Often performed as part of greetings to show respect; in traditional rituals and/or as a sign of contrition when dealing with authority.
} 
mother. This incenses the married man. Onlookers suggest that the young man 'be beaten thoroughly' ${ }^{65}$ to make him speak Shona and also confess the real reason for being at the married man's house with his wife. The exchange between the men shows gender and age relations in a state of flux hence the brazen adultery. It shows that norms alone are no longer enough to secure a married man's home/house and wife as his private space. There are tsotsis, who typically operate outside norms, challenging him behind his back. The lovers had locked the house and apparently did not hear him knocking forcing the married man to break the door to get in.

Clearly, the view that interpersonal violence is appropriate for people who cross boundaries of propriety by engaging, for example, in adulterous affairs still holds. Offenders know they get no public sympathy. The acceptance of violence to modify behaviour of others to obey rules, demarcations of space is used in political rivalries too. In both instances, violence is used to extract information and cooperation from wayward individuals. Violence is a means by which men mark out their territory, including women, and which political parties identify supporters and discipline opponents. The ubiquity of violence justifies married man taking the law into his own hands to defend his interests and to keep his wife in a place of dependency since material resources alone have not achieved this. Thus in the song, the confrontation is clearly between the young man and the married man; the woman is the territory being struggled over. This may point to the objectification of women, but it is not a situation created by artists. It is part of Zimbabweans' lived realities and part of realities of most men.

Xtra Large draw from a story wildly circulated in Harare's grapevine a decade or so ago in which a young male professional who dated the same woman as a powerful minister was caught at the woman's flat. The younger man was apparently given two options either to sit on a pre-heated hotplate or to jump from the window/balcony of the flat a couple of floors above ground. He chose to jump and sustained irreparable damage to the spine making him a wheelchair user for life. In the Xtra Large lyrics, the wayward young man is given the same options, but luckily he escapes and the song ends with a warning to young men that dating married women is dangerous. By drawing on a real event, the lyrics show that the song is not about hypothetical events, they recall events that some officials would rather forget.

As discussed in the song House gero, female youth's agency in sexuality is seen when married women on extended periods of cross-border expeditions to South Africa, leave maids to run households. The domestic worker takes control, including being sexually available to the

\footnotetext{
${ }^{65}$ Ukarohwa uchataura..... (that is, 'you will confess after a good beating') and later urging the angry man 'Nyatsomurova...', (that is 'beat him hard'.)
} 
man of the house. Such affairs take place in full view of children of the couple. In the song, the affair is discovered by the cross-border trader when a child blurts out that in her absence, that their father was scared to sleep alone and sought the maid's company. This childish disclosure of sexual impropriety is unsettling albeit innocent. Although based on a widely circulated joke in the streets of Harare, these lyrics underline anxieties around having non-kin females doing intimate care work in one's house. They show domestic workers as having the advantage of being available to prove or at least perform their domesticity while their mistresses are away earning money. These are topical issues in Zimbabwe.

Jerry, Shayndingz and colleagues in their hedonistic song 'Tipei maoko ${ }^{\prime 66}$, perhaps show the pervasiveness of extramarital affairs in that increasingly, men do not hide their family status and often display them, suggesting perhaps that among (young) men there is no contradiction, and what matters is what happens in those spaces where they meet other partners. The artists describe themselves as 'tiri madhara emafaro' ('we excel in having fun'). Jerry says at the beginning of the song,

Ndeipi bhebhi, ndinonzi Jedza Kana kuti Baba Anisha Pamafaro ndinonzi Manager

Ndinomwa kusvika kwaedza [....]
Hey baby, I am Jedza

Or call me Father of Anisha

When having fun I'm called 'the Manager'

I drink until daybreak

The men shown here present multiple identities as individuals, fathers, husbands seeking extramarital affairs and bingeing on alcohol to showcase their masculinity. This self-introduction is clearly about the moment - having fun. Neither are obligations to Anisha and her mother are not presented as contrary to chatting up 'babes' and likely sexual liaison nor the 'drinking until daybreak'. We are presented with contradictory roles as co-existing seemlessly. Presenting himself as 'the manager' in recreational spaces, Jerry's alter ego is indispensable to targeted young women seeking fun 'till dawn'. Mastery of resources for the latter makes male youths sought after by female counterparts. Female dependence on males is established.

To adults, the public display of adultery is shocking, they would rather adultery is hidden to protect the 'sanctity' of marriage by allowing deniability of its pervasiveness. Youth dispense with the denial. Thus while not debunking marriage as an institution; they redefine its

\footnotetext{
${ }^{66}$ A Shona version of popular hip-hop chanting in which people on the dance floor simultaneously raise/wave their hands and chant/scream in response to prompts by a disc jockey/emcee.
} 
sanctity differently by acknowledging the possibility of concurrent relations. The lyrics show emerging ways of being among young males (and females) in Zimbabwe. Their narrative is supported by findings of a ten country study of multiple and concurrent partnerships in Southern Africa, which shows such relationships are increasingly common. ${ }^{67}$

Like in previous songs, violence is used to control interactions and access to recreational spaces with competitors and gatecrashers threatened with beatings by bouncers. Verbal abuse is used to keep out older women and to remind them about dress codes of these spaces presented as excluding styles typical of 'mothers' such as 'dresses', 'head scarves' and 'plastic slippers' but favour 'hipsters', 'miniskirts' and the 'display of beautiful legs'. ${ }^{68}$ The recreational spaces are clearly youthcentric and meant for androcentric pleasures. Young men pursue hedonism, using their resources to subjugate female peers and deploying discourses of propriety to keep older women away.

Two songs, Tipei Maoko and Celebrity show contradictions in hedonist pursuits and expectations for socially approved spending. The former make male youth madhara for the moment but makes it hard to achieve the latter. In Celebrity, anxiety about survival, marriage and consumption are brought into relief because of limited disposable income. The 'celebrities' (youth artists) of the lyrics, wear borrowed clothes, beg for food, rent rooms in low income areas, sleep on the floor (because they cannot afford beds), get by on casual paid sex and yet are always on television and have expensive cellphones. These men are referred as 'kamudhara', 'bhanditi' albeit 'wizard of fun'/ 'leisure' (muroyi wemafaro). Such men, a female member of the group laments, are unmarriageable because they have no money to pay bridewealth and are thus not worth dating. Both songs show an awareness of contradictions of existences and identities based on living for the moment. It is one thing to be a big dhara at a party/show and another to invest in having an independent patriarchal household as society expects. Clearly many youths face challenges in this area.

The foregoing shows the agency of sugar mamas, and of male and female youths who date older partners pointing to social relations in state of flux. This narrative unsettles normative narratives of asexual, voiceless and invisible unmarried youth especially female youths. ${ }^{69}$ Youths call on adults (men and women) to account, to hold their side of

\footnotetext{
${ }^{67}$ Soul City, 'Multiple and concurrent partnerships in Southern Africa: a ten country research report' (2008) Johannesburg: South Africa

68 ،...hapabvumidzwe madhirezi nemadhuku .../..mapatapata ..../Panodiwa mahipsters, ma mini...../'

${ }^{69} \mathrm{R}$ Marindo, S. Pearson and J.B. Casterline, 'Condom use and abstinence among unmarried young people in Zimbabwe: which strategy and whose agenda?' (2003) Washington DC: Population Council
} 
the bargain in intergenerational relations rather than blame youths for the chaos. It shows youth as potential predators too.

\section{d) On the objectification of women}

'Objectifying women' means presenting women as dehumanised and objects for male sexual pleasure. ${ }^{70}$ As Saul says, objectification precludes the participation of women and girls in how they are defined: their interests and needs are seen as of no consequence to satisfying male objectives in a heterosexual setting. Objectification is about power relations, and is also contextual. This notion of objectification is a source of hip-hop's notoriety. However, it is challenged by situations where women deliberately collude with objectification of their likenesses or bodies in exchange of money or to challenge societal views. Thus objectification is nuanced. Women's bodies are sexualised (much like in soukous, kwaito, ragga videos) and fetishised hence Miller-Young refers to 'the pornification' of hip-hop. ${ }^{71}$ In addition, hip-hop relies on provocative use of language to capture evolving subjectivities and challenge the status quo. For instance, women in hip-hop videos are referred to as 'video "hos"' (calibrated from whore) and 'bitches' but whose meanings in colloquial English is different from what these words conjure up in standard English. ${ }^{72}$ This is to say the words and images are not meant to insult women. In the northern hemisphere some of the women in the videos may work in adult entertainment and see hip-hop videos as diversification of their work and sources of income under less hazardous working conditions. ${ }^{73}$ Thus when objectification is juxtaposed with agency and consent of women, it make uni-dimensional charges of objectification unsustainable. ${ }^{74}$

In Zimbabwe, videos are currently few, shifting importance to the lyrics, their contextual meanings. As the stories in the cited songs show, women are discussed in a context of neo-patrilineal identities as

70 J Saul, 'On treating things as people: objectification, pornography and the history of the vibrator' , Hypatia 212 (Spring 2006) pp 45-59

${ }^{71}$ Miller-Young, 2007, ibid pp263-264

${ }^{72}$ For instance, see www.urbandictionary.com (accessed 20 September 2011); an online user generated dictionary of English slang. A 'video ho' is a woman or man who likes to draw attention to him/herself by being filmed near stars, wearing revealing clothes or doing things which draw attention to stand out in a video. 'Bitch' means whining excessively, doing degrading work or to express hardship.

${ }^{73}$ Miller-Young, 2007 ibid p263

${ }^{74}$ These debates are too complex to get into because of limitations of space and scope. See for instance, T. Truong 'Sexual labour in contemporary capitalism' (1998) Journal of Gender Studies 1 pp 9-21 
potential wives or as non-marriageable within a neo-patrilineal and consumerist context. The ideal of the male provider persists even when employment opportunities are limited. Thus males who can access resources can assert control over women and affirm their manliness in both long term and short term relations. By contrast, men with limited access to resources are not respected, as their masculinity is much harder to showcase. Women collude with these ideals as they want men of means as partners to affirm their own statuses as married women. When marriage is not forthcoming, manliness is affirmed short-term relations where cash exchange takes place. This is reflected in Celebrity, where a woman says repeatedly, 'Unondipei?' ('What will you do for/give me?') to challenge an emergent urban grooves artist who appears successful but lacks resources to go with the image. Because marriage is ideally preceded by bridewealth in hard currency, no woman wanting to be celebrated in her family would attach herself to a man known to be unable to pay bridewealth or give gifts in hard currency. Thus in Zimbabwe singing about men needing/having money to retain women's attention (or women looking for such) is not objectifying women in itself. Instead it is a reality which speaks to deep-seated female dependence on men, perpetuated by bridewealth norms and unequal opportunities between men and women. This makes relatively poor women relate to men instrumentally.

The use of street terms for young women may also be seen a form of objectification. However when considered together with names for men, it is clear that they are categories which speak to emerging subjectivities punctuated by consumerism and related sexualities. Girls are referred to as (among other things) koso, chimoko, jimbisi, (whore), gero (girl), bhebhi (baby/babe), and chi-danger. The latter means literally- a small dangerous escapade/something that gets one into trouble. For instance, a childhood sweetheart is referred to as 'chimoko' and 'chi-danger' in a song by Nasty Trix. Perhaps the term refers to the dangers of dating, since beyond risks of sexually transmitted infections including HIV, when girls and boys are out late chances are boys are blamed for it. Boys are responsible when their partners are chased away from home, thereby expediting initiation of marriage negotiations to salvage the girl's family honour. Boys with no resources know that this inconveniences their families.

In general, such terms judge social standing and suggest different types of (sexual) relations that males can get into with the women. Although some of the words originate from English, origins of chimoko and koso are not immediately discernible nor are their meanings. Perhaps, it is their incomprehensibility which is most confounding, given their common usage. In addition, many of them remove girls/women from class 1 nouns. However, there is no discernible protest against these labels by female youth. Females too categorise men and women based on sexuality and consumerism. Mhene, for instance, is a street term for 
men with disposable income, who are seen as ideal short or long term (sex) partners; or benevolent patrons. Terms used by Zimbabwean females are not discernible in songs under discussion which is not surprising given these artists are largely male, with storylines from a male perspective. Elsewhere in Sub-Saharan Africa, studies show that female youth also objectify and label men according to their utility to female youth aspirations; with labels referring to sexual access, gullibility and/or generosity. ${ }^{75}$

Men call likable male peers machinda (lads), ma-face (friends), boys, madhara (as explained in the foregoing). Male peers who have sex with men are referred to using the homophobic term 'ngochani'. Peers given to hooliganism and quirkiness are madinga/magora, (in English 'feral cats'), mabhanditi, ('bandits' although in mainstream English this would be translated as 'convict'). Mabhanditi are defined by their despair; sometimes also referred to as 'boora ngoma' (literally - one who breaks drums) meaning a disruptive person. Men with no money but also given to eccentricity are kamudhara. Controversially, hooligans are called 'comrades'. ${ }^{76}$ In mainstream political discourse, the term 'comrade' refers to individuals at the top of the ZANU-PF hierarchy and known for their role in the liberation war. ${ }^{77}$ Alternately comrade refers to a temperamental and quirky individual who does not care about prevailing norms. This perhaps is an oblique reference to the conduct of some war vets in fast track land reform. Depending on the context, individuals labelled as 'comrades' are admired for their boldness but may also be resented for selfishness when they ride roughshod over others.

\section{Discussion: policing and being challenged by youth}

Sociologists have long shown that being alarmed by youth speaks of far reaching changes in social relations- the kind that marginalises the unemployed, low income groups - which those in the establishment are not sensitive to. Often youth or their deficient upbringing is seen as the problem. In this case, contributing to the nation is seen as issue even when there is no work. Despite the top-down nature of 'cultural nationalist' strategies which sought to inoculate youths against 'foreign influences', ${ }^{78}$ lyrics analysed in this paper show that youths are not

\footnotetext{
${ }^{75}$ For instance, F B Nyamnjoh, 'Fishing in troubled water: disquettes and Thiofs in Dakar' (2005) Africa 75 3; K Longfield. 'Rich fools, spare tyres and boyfriends: partners categories and relationship dynamics and Ivorian women's risk for STIs and HIV' (2004) Culture, Health and Sexuality 66 pp483-500

${ }^{76}$ Similarly 'war vet' is interchangeable with 'hooligan' in popular parlance, see Eyre 2005 ibid pg 29

77 In official circles, the title 'Comrade' silences academic/professional titles.

${ }^{78}$ Ndlovu-Gathseni and Willems, 2009 ibid
} 
dupes. Officials, who had not factored in unintended effects of using local colloquial languages, ended up on the defensive by banning some songs. Not only do colloquial versions of local languages deviate from grammatical rules and attendant cultural norms, they allow for the narration of practices which officials would rather are not publicised. In this vein urban groovers are with cultural nationalists in use of vernacular languages, but typically comment on contradictory changes since 2000 and the resultant unfolding chaos in social relations including intergenerational, premarital and extramarital sex. Youth artists show that since the 2000 demands for survival and consumerism, and the patronage and instrumentality they entail challenge norms, that maintain distance between people of different genders and generations. As Jones shows, this increased toleration of the illicit. ${ }^{79}$ Under these conditions people are respected conditionally depending on what they do to/for/with those granting respect. Respect is earned instrumentally. Hence for youths' short and long term needs, schemata to categorise people as useful. Being able to draw on local languages for signifiers of these categories undermined assumption that performances in local languages would, for 'cultural reasons' not be amenable to sexually explicit material. Sexually explicit language and performance are part of Shona culture, as the traditional poetry referred to above shows. Perhaps, sexually explicit lyrics are seen as denoting hypersexuality and therefore inappropriate.

Youth lyrics show acute awareness of social structure and its norms. They sing about expectations to marry women with high demands in contexts in which pervasive unemployment precludes marriage because of resource austerity. Meanwhile, conforming to a stereotypical ideal of depending on a man, females serially attach themselves to different men with disposable income. When youth talk about this they are seen as challenging the status quo through disclosing these dissonances.

That youth lyrics are banned for objectification of women raises more questions than answers. Objectification, is about women who are rendered passive because they are defined and talked about in androcentric ways. Yet, urban grooves songs show women who talk back, argue and tell off men as they negotiate terms of interaction. ${ }^{80}$ This is less objectification that the recognition women talk back, take issue with what they do not like. It shows women's sexual agency in heterosexual settings of neo-patrilineal patriarchies is made to look

\footnotetext{
79 J Jones, 2010, ibid

${ }^{80}$ D Bhana, R Morrell, J Hearn and M Moletsane, 'Power and identity: an introduction to sexualities in Southern Africa '(2007) Sexualities, 10, 2 pp131139
} 
deviant. ${ }^{81}$ It shows less directly that women's organisations seeking to empower women, are unsure about what to make of notions and practices of female sexual passivity and naiveté typical of heterosexual settings. On one hand these groups take passivity as an essential quality of women, to be preserved to ensure women's 'dignity' and 'decency'. On the other hand they also embrace sexual (health) rights approaches where disclosure of sexual experiences is par for the course. In addition, there these organisations seem to have an underlying need to counter stereotypes of African hypersexuality hence a vested interest in discourses which play down women's sexual agency. Thus it is simplistic to charge that urban grooves denigrate women for showing them as sexually active, agentive and seeking economic security through heterosexual relations.

Highlighting that youth artists are foul-mouthed may be a ploy to sustain gerontocratic dominance and not deal with experiences that youth talk about, in the same way that conservative interests dismiss feminist activists as 'western', 'un-African' and anti-family. Thus gender activists who see the objectification of women collude with conservative systems which oppress them too. This clearly shows the need to deal with emerging music styles from a youth perspective and to use a gender lens within this. Meanwhile, the complaint about objectifying women plays down ethnocentrism and homophobia among youth artists. The ban shows adults' hypocrisy vis-a-vis youth. Why else would it be offensive to hear anti-HIV, marriage and sexuality messages as performed by urban groovers when older musicians such as Oliver Mtukudzi sing about the same issues?

\section{Conclusion}

Youth society relations have not been examined and critiqued in Zimbabwe, particularly how they shaped the Third Chimurenga. By looking at youth activities in the form lyrics of nascent music styles, this paper shows that youth artists were driven by unemployment and new opportunities occasioned by cultural nationalist activities to localise entertainment products. For officials, this had unforeseen effects, exposing the dissonances between assumptions about Zimbabwean culture in official discourses and lived experiences as observed by youths. The latter undermines official narratives of 'African' / 'our culture $^{\prime 82}$ as an unchallengeable, foundational, seemingly shared and unique ethos. As the paper tries to show, challenges to gerontocracy are

\footnotetext{
${ }^{81} \mathrm{~T}$ Shefer and D Foster, ' Discourses on women 's (hetero)sexuality and desire in a South African local context' Culture, Health and Sexuality, 34 (2001) pp 375-390

${ }^{82}$ L B Christiansen, “"In our culture” - How debates about Zimbabwe's Domestic Violence Law became a "cultural struggle"', NORA-Nordic Journal of Feminist and Gender Research 17, 3 (2009) pp 175-191.
} 
on-going. As the textual analysis provided here indicates, these challenges can be seen in youth music, a source of meanings about emerging gender and sexual subjectivities. 